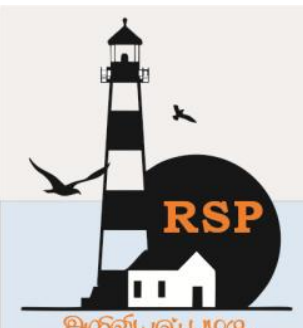

INTERNATIONAL RESEARCH JOURNAL ON ADVANCED SCIENCE HUB

\title{
Evaluation of Compressive Strength of Concrete Made With Fly Ash and M Sand
}

N. Uday Kiran ${ }^{1}$,S.Hanmanthu ${ }^{2}$, C. Govardhan ${ }^{3}$, Dr. V. Gayathri ${ }^{4}$

${ }^{1}$ Assistant Professor,Department of Civil Engineering,Annamacharya Institute of Technology \& Sciences, Telangana,India.

${ }^{2}$ Assistant Professor,Department of Civil Engineering,Annamacharya Institute of Technology \& Sciences, Telangana,India.

${ }^{3}$ Research Scholar,Department of Civil Engineering,Kumaraguru College of Technology, Tamil Nadu,India.

${ }^{4}$ Associate Professor,Department of Civil Engineering,Kumaraguru College of Technology,Tamil Nadu,India.

govardhan.123.4you@gmail.com ${ }^{3}$

\begin{abstract}
Concrete is the most commonly used material by humans which stands next to the water in terms of consumption in the world. Due to the rapid growth in the construction sector, the amount of concrete to be used is increasing day by day which requires a huge quantity of natural materials such as river sand and aggregates. Due to the illegal sand mining and overexploitation, the availability of river sand is getting scarce day by day. The cement which acts as a binding material is one of the important materials in concrete. The most commonly used cement is Portland cement. For the generation of 1 ton of cement, approximately 1 ton of $\mathrm{Co}_{2}$ is released into the atmosphere. To overcome these problems, Supplementary cementitious materials to be used as a replacement for the cement. In this experimental work, fly ash and $M$ Sand are used as a replacement to the cement and river sand. The strength properties such as compressive strength and tensile strength were compared with the conventional concrete of M25 grade with the concrete made by using replacement materials.
\end{abstract}

Keywords: M Sand, Fly Ash, Compressive Strength.

\section{Introduction}

Concrete is the most common and widely used material in the construction industry all over the world. The constituents of concrete arebinding material,Fine and coarse aggregates, and water. Sometimes, admixtures are also used. The most commonly used binding material in concrete is cement. There is a variety kind of cement available in the market. Depending upon the situation, a suitable type of cement is used. Among all the varieties of cement, Portland cement is most commonly used in all the general works of construction. When comes to the fine aggregate, natural river sand conforming to zone - II will be used in the concrete. Due to the rapid industrialization and urbanization, the consumption of concrete for meeting the abovementioned needs are increasing day by day which leads to an increase in consumption of naturally available materials such as river sand. In general, for the production of 1 ton of cement, approximately 1 ton of $\mathrm{Co}_{2}$ is released into the atmosphere which is a threat to the environment creating an impact on human life[1]. Hence, the researchers are focusing to use available alternate materials in the concrete which preserves the environment from negative impacts, savings in the 
www.rspsciencehub.com

natural resources, and economy in construction. Keeping the above things in point of view, fly ash and $\mathrm{M}$ sand are used in concrete and the strength properties were evaluated and compared with conventional concrete of M25 grade.

\section{Experimental Program}

\subsection{Materials}

The materials used in this experimental work are:

Cement:Ordinary Portland cement of 43 grade is used and tests such as consistency, IST, and FST were evaluated.

\section{Table.1.Physical properties of cement}

\begin{tabular}{|l|l|l|}
\hline S. No & Property & Value \\
\hline 1 & Specific Gravity & 3.1 \\
\hline 2 & $\begin{array}{l}\text { Standard } \\
\text { Consistency }\end{array}$ & $32 \%$ \\
\hline 3 & IST & 38 minutes \\
\hline 4 & FST & 520 minutes \\
\hline 5 & Soundness & $1 \mathrm{~mm}$ \\
\hline
\end{tabular}

Fine Aggregate: Locally available river sand free from debris and inorganic impurities and confirming to Zone- II as per IS: 383-1987[2] is used.

Table.2.Physical properties of river sand

\begin{tabular}{|l|l|l|}
\hline S. No & Property & Value \\
\hline 1 & Specific Gravity & 2.58 \\
\hline 2 & $\begin{array}{l}\text { Bulk Density (Loose } \\
\text { state) }\end{array}$ & $1392 \mathrm{~kg} / \mathrm{m}^{3}$ \\
\hline 3 & $\begin{array}{l}\text { Bulk Density (Dense } \\
\text { state) }\end{array}$ & $1604.6 \mathrm{~kg} / \mathrm{m}^{3}$ \\
\hline 4 & Water absorption & $1.48 \%$ \\
\hline 5 & Fineness Modulus & 2.34 \\
\hline
\end{tabular}

Coarse Aggregate:Crushed aggregates of $20 \mathrm{~mm}$ nominal maximum size are used and tests are done confirming to IS:383-1987[2].

Table.3.Physical properties of coarse aggregate

\begin{tabular}{|l|l|l|}
\hline S. No & Property & Value \\
\hline 1 & Specific Gravity & 2.81 \\
\hline 2 & $\begin{array}{l}\text { Bulk Density (Loose } \\
\text { state) }\end{array}$ & $1690.15 \mathrm{~kg} / \mathrm{m}^{3}$ \\
\hline 3 & $\begin{array}{l}\text { Bulk Density (Dense } \\
\text { state) }\end{array}$ & $1936.54 \mathrm{~kg} / \mathrm{m}^{3}$ \\
\hline 4 & Water absorption & $0.82 \%$ \\
\hline 5 & Fineness Modulus & 6.4 \\
\hline
\end{tabular}

Volume 02 Issue 10 October 2020

Water: Water available in the vicinity of college premises is used for curing and concreting as per IS:456-2000.

\subsection{Fly Ash:}

As coal is used as a fuel in power plants, it is burned at high temperature and non-combustible minerals occur due to the burning of coal and a kind of ash is extracted by using electrostatic precipitators from the flue gases is known as Fly Ash[3]. Fly Ash is a mineral admixture and can be used in concrete as a replacement to the cement[4]. The incorporation of fly ash influences the fresh and hardened properties of concrete[5].

Table.4.Chemical Composition of Fly Ash

\begin{tabular}{|l|l|l|}
\hline S. No & Chemical & \% of mass \\
\hline 1 & $\mathrm{SiO}_{2}$ & 53.90 \\
\hline 2 & $\mathrm{Al}_{2} \mathrm{O}_{3}$ & 27.10 \\
\hline 3 & $\mathrm{Fe}_{2} \mathrm{O}_{3}$ & 6.80 \\
\hline 4 & $\mathrm{CaO}$ & 8.80 \\
\hline 5 & $\mathrm{Mgo}$ & 1.60 \\
\hline 6 & $\mathrm{So}_{2}$ & 0.60 \\
\hline 7 & $\mathrm{Na}_{2} \mathrm{O}$ & 0.60 \\
\hline 8 & $\mathrm{~K}_{2} \mathrm{O}$ & 0.60 \\
\hline
\end{tabular}

\subsection{Sand:}

M Sand commonly known as Manufactured Sand is obtained by crushing the rocks to a particular size which is then sieved properly to meet the requirements of natural sand to be used as a fine aggregate[6]. It is also called as artificial sand[7]. The shape of the MS particles are angular and has rough surface texture while the RS particles are round in shape with smooth surface texture[8].

Table.5.Properties of M Sand

\begin{tabular}{|l|l|l|}
\hline S. No & Property & M Sand \\
\hline 1 & Specific Gravity & 2.56 \\
\hline 2 & Water Absorption & $2.24 \%$ \\
\hline 3 & Fineness Modulus & 2.65 \\
\hline 4 & Surface Texture & Rough \\
\hline
\end{tabular}

Table.6.Mix Design for conventional concrete

\begin{tabular}{|l|l|}
\hline Mix Designation & M \\
\hline Cement & OPC 43 Grade (100\%) \\
\hline River Sand & $100 \%$ (Zone - II) \\
\hline Coarse Aggregate & $100 \%$ \\
\hline Fly Ash & $0 \%$ \\
\hline M Sand & $0 \%$ \\
\hline
\end{tabular}


Table.7. Notations for Mix Design of Concrete with various levels of replacement

\begin{tabular}{|c|c|c|c|c|c|}
\hline & \multicolumn{5}{|c|}{ Mix Designation } \\
\hline Material & MA & MB & MC & MD & ME \\
\hline Cement & $95 \%$ & $90 \%$ & $85 \%$ & $80 \%$ & $75 \%$ \\
\hline Fly Ash & $5 \%$ & $10 \%$ & $15 \%$ & $20 \%$ & $25 \%$ \\
\hline M Sand & \multicolumn{5}{|c|}{$100 \%$} \\
\hline $\begin{array}{c}\text { Coarse } \\
\text { Aggregate }\end{array}$ & \multicolumn{5}{|c}{} \\
\hline
\end{tabular}

Table.8. Experimental Results of Compressive Strength

\begin{tabular}{|c|c|c|c|c|c|c|}
\hline Mix Designation & M & MA & MB & MC & MD & ME \\
\hline Compaction Factor & 0.89 & 0.89 & 0.87 & 0.86 & 0.84 & 0.81 \\
\hline $\begin{array}{c}\text { Compressive } \\
\text { Strength at 7 days in } \\
\text { MPa }\end{array}$ & 20.20 & 23.30 & 24.22 & 23.96 & 22.78 & 19.86 \\
\hline $\begin{array}{c}\text { Compressive } \\
\text { Strength at 28 days in } \\
\text { MPa }\end{array}$ & 26.54 & 30.24 & 31.43 & 29.26 & 26.98 & 23.98 \\
\hline $\begin{array}{c}\text { Compressive } \\
\text { Strength at 56 days in } \\
\text { MPa }\end{array}$ & 31.96 & 32.85 & 35.48 & 32.62 & 30.1 & 26.5 \\
\hline
\end{tabular}

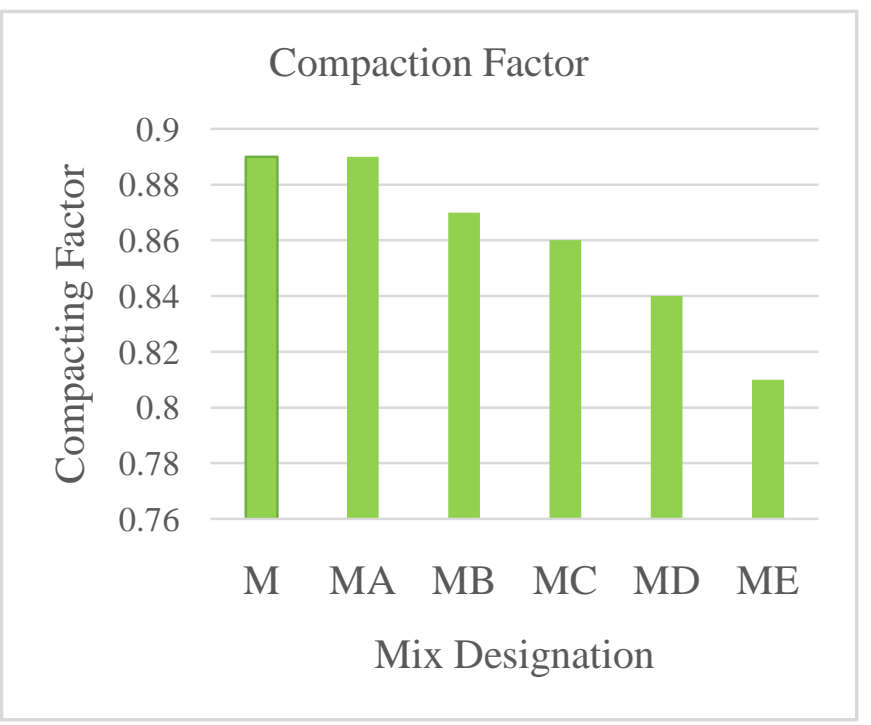

Chart.1.Compaction Factor

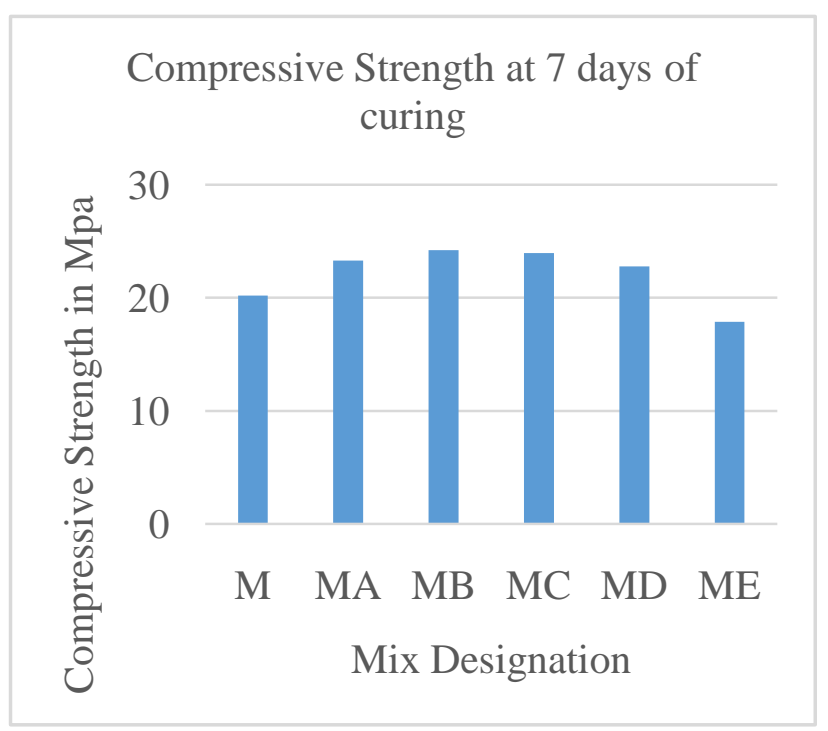

Chart.2. 7 days Compressive Strength 


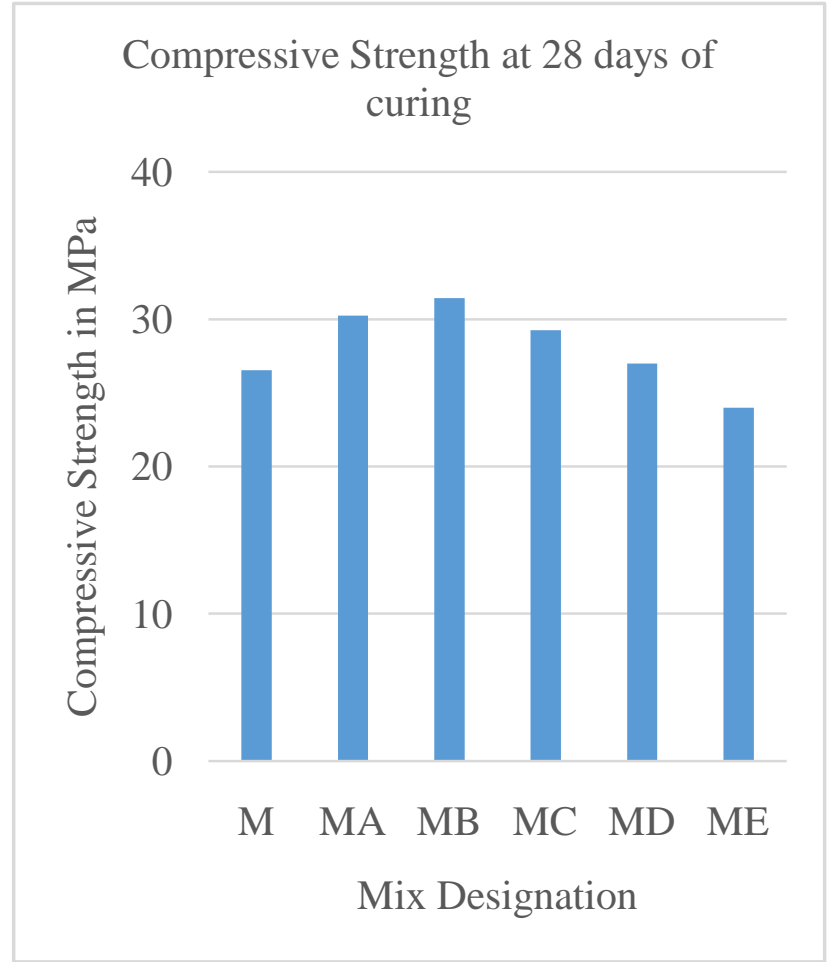

Chart.3. 28 days Compressive Strength

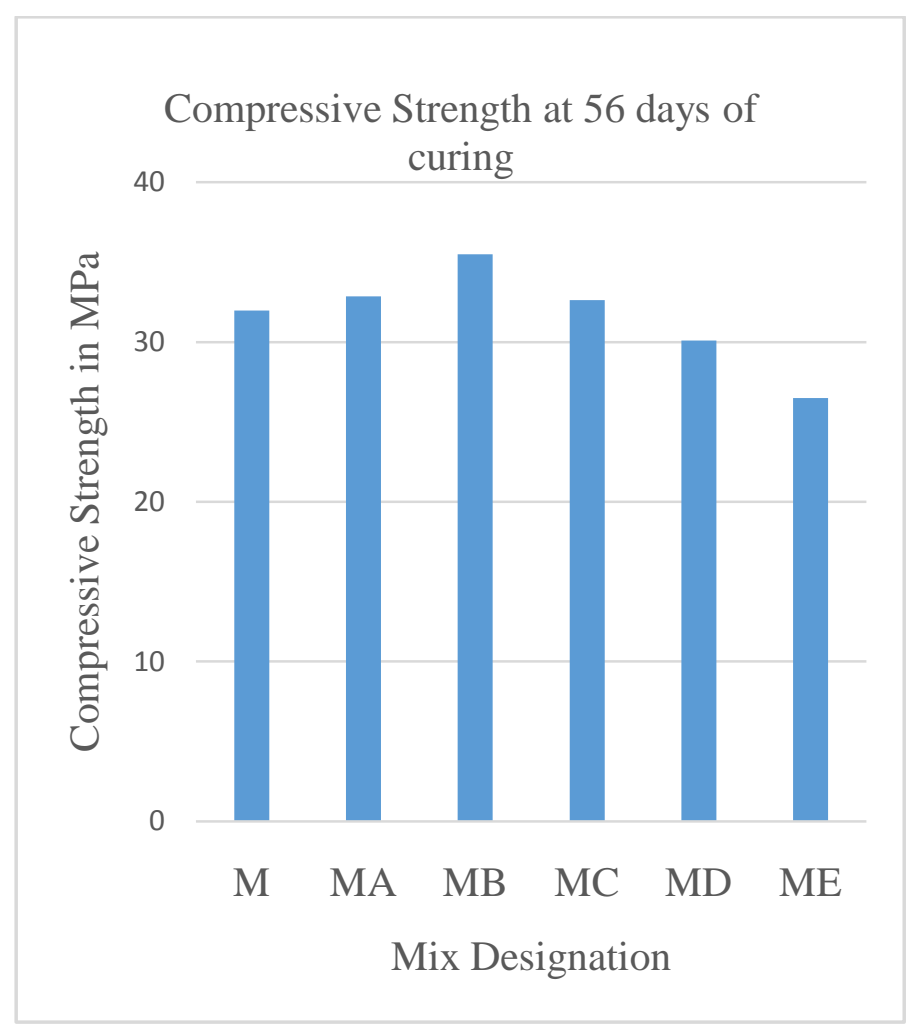

Chart.4. 56 days Compressive Strength

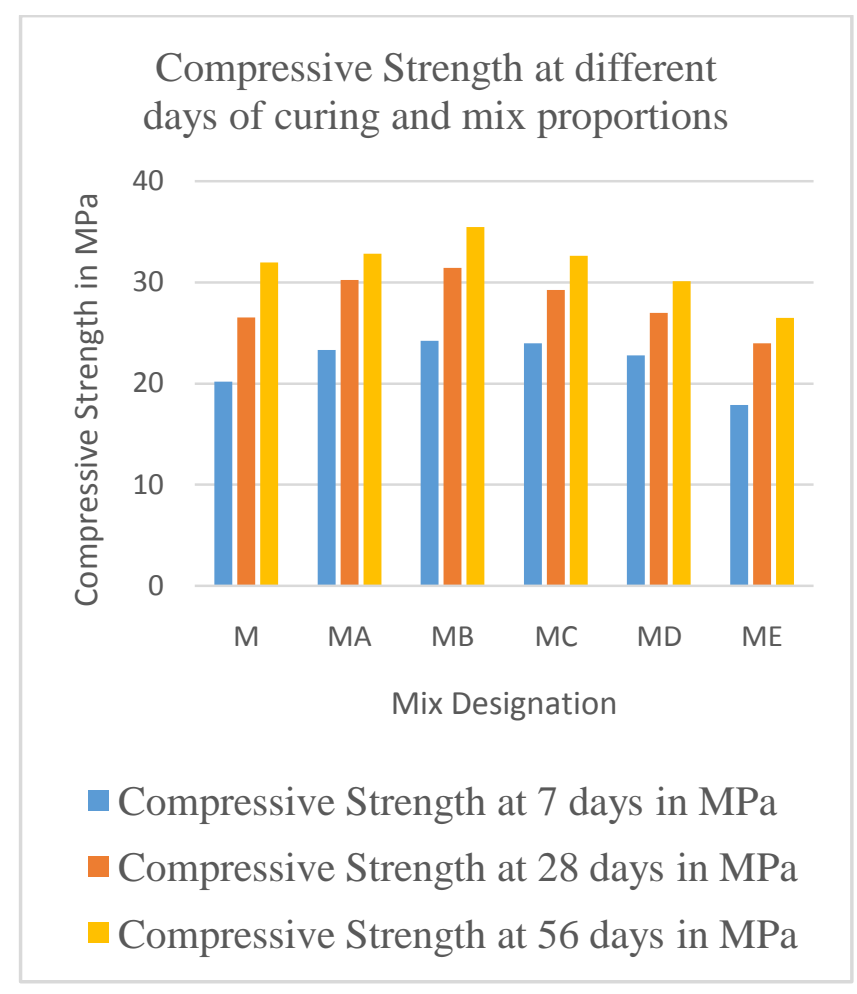

Chart.5. Compressive Strength at different days of curing and mix proportions 


\section{Conclusions:}

1. Compaction Factor decreases with increase in percentage of fly ash.

2. With $10 \%$ replacement of fly ash and 100 $\%$ of $\mathrm{M}$ sand gives optimum strength at 7 days of curing.

3. With $10 \%$ replacement of fly ash and 100 $\%$ of $\mathrm{M}$ sand gives optimum strength at 28 days of curing.

4. With $10 \%$ replacement of fly ash and 100 $\%$ of $\mathrm{M}$ sand gives optimum strength at 56 days of curing.

5. Keeping the percentage of $\mathbf{M}$ sand as a constant, with the increase in percentage of fly ash the compressive strength increases and then decreases at all days of curing.

6. When compared with the conventional concrete, concrete made with $10 \%$ fly ash and $100 \%$ M Sand at 7days, 28 days and 56 days of curing gave optimum strength.

\section{References}

\section{Journals}

[1] R. Joshi, "Effect on Compressive Strength of Concrete by Partial Replacement of Cement with Fly ash," Int. Res. J. Eng. Technol., vol. 4, no. 2, pp. 315-318, 2017, [Online].Available:

https://irjet.net/archives/V4/i2/IRJETV4I2392.pdf.

[2] B. I. S. (BIS), "IS 383: 1970 Specification for Coarse and Fine Aggregates From Natural Sources for Concrete," Indian Stand., pp. 1-24, 1970.

[3] M. Abushad and M. D. Sabri, "Comparative Study of Compressive Strength of Concrete with Fly Ash Replacement by Cement," Int. Res. J. Eng. Technol., vol. 4, no. 7, pp. 2627-2630, 2017, [Online]. Available: https://irjet.net/archives/V4/i7/IRJETV4I7534.pdf.

[4] K. V. Sabarish, R. V. Raman, R. Ancil, R. W. Raja, and P. S. Surendar, "Experimental studies on partial replacement of cement with fly ash in concrete elements," Int. J. Civ. Eng. Technol., vol. 8, no. 9, pp. 293298, 2017.

[5] P. P. Jayeshkumar, D. L.B.Zala, and
Dr.F.S.Umrigar,"Experimental

Investigations on Partial Replacement of Cement With Fly Ash In Design Mix Concrete," Int. J. Adv. Eng. Technol., vol. III, no. IV, pp. 126-129, 2012.

[6] S. K. Y. Yajurved Reddy M, D.V. Swetha, "Study on Properties of Concrete With Manufactured Sand As Replacement To Natural Sand," IJCIET_10_03_202 Int. J. Civ. Eng. Technol., vol. 6, no. 8, pp. 29-42, 2015, doi: 10.17485/ijst/2015/v8i36/88614.

[7] V. R. Supekar and P. D. Kumbhar, "Properties Of Concrete By Replacement Of Natural Sand With Artificial Sand," vol. 1, no. 7, pp. 1-7, 2012.

[8] W. Shen et al., "Characterization of manufactured sand: Particle shape, surface texture and behavior in concrete," Constr. Build. Mater., vol. 114, pp. 595-601, 2016, doi: 10.1016/j.conbuildmat.2016.03.201. 